\title{
FAMILY FINANCIAL MANAGEMENT TRAINING IN KELURAHAN RAWA BUAYA
}

\author{
Mochamad Mukti Ali \\ Faculty of Economics and Business, Mercu Buana University \\ mukti_gte@yahoo.com
}

\begin{abstract}
The family is a collection of people consisting of father, mother, and children who have similar problems in the field of household economy and these problems must be solved together. In order for each household to live in prosperity, its members must strive to improve their household's economy. These efforts are mainly family financial arrangements. This financial arrangement means that you can adjust your money in with money out. Family financial management is a way of managing family finances regularly and carefully through the stages of planning, implementation, and supervision/assessment. This management skill is very important to be owned by every family because the adequacy of family income depends on how to manage the family's economy. The results of the training evaluation revealed that participants stated that training was very useful to improve understanding regarding the effectiveness of interpersonal communication in managing family finances.
\end{abstract}

Keywords: Family financial management, interpersonal communication, managing

family finance

\section{INTRODUCTION}

The family is a collection of people consisting of father, mother, and children who have similar problems in the field of household economy and these problems must be solved together. Their provision is a shared will, to overcome common problems by utilizing the resources they have. Families can overcome the problem of their needs in the household if there is a good cooperative relationship between members within the family itself. Network with outsiders can support the development of businesses that will be developed.

In order for each household to live in prosperity, its members must strive to improve their household's economy. These efforts are mainly family financial arrangements. This financial arrangement means that you can adjust your money in with money out. It often happens in the household, that money comes out more than money coming in, so life like that is difficult to live a prosperous life. Therefore, it must be endeavored to make more money than money out. So that there is always more money left in the financial management of the family. There are two ways that can be taken. First, the family can control money out. Secondly by increasing the economic capacity of households.

Control of money comes out, does not mean being stingy, but we can consider carefully, earnestly and openly, what activities will be financed. Whether the activity is something that is needed by the family or just a desire that can still be postponed. Managing family finances seems so simple. But in practice, there are many people who are unable to manage it properly. This is not a matter of big or small salary/income received, but rather how to spend the money in a directed manner in accordance with the designation based on the priority scale. This simple budget allocation and family expenditure (household) if not managed properly gives birth to a family - families who dig a hole in the hole. Life is always less and less, even though the nominal income has increased. This is certainly not just a personal matter, because it will directly or indirectly affect a person's performance in working in their respective work environments. Try to imagine how someone can work well, full of integrity and dedication if the salary he receives every month is only half or less than the amount that must be 
received, because of a large amount of debt/loan cut. Or the salary he earns is only enough until the middle of the month, after that look for loans and loans again.

Family financial management is a way of managing family finances regularly and carefully through the stages of planning, implementation, and supervision/assessment. This management skill is very important to be owned by every family because enough or not family income depends on how to manage the family economy. Without knowledge of financial management, especially financial planning, the family economy can be "messy", so that family life becomes unsettled and family welfare is not achieved. Even further consequences can cause family rifts. A regular economy is one of the conditions in achieving the peace of mind of all family members. Therefore it is necessary to strive, especially for housewives as family financial holders to always be wise in meeting the needs of their families.

\section{LITERATURE REVIEW}

According to Ahmad Gozali (2006) tips for success in family financial management can be taken with the following steps, namely:

First, Every time you receive a salary, the most important first step that must be done first is to pay debt repayments first. Because debt is the most important obligation that must be fulfilled to other parties whether from banks and other financial institutions. The discipline of paying installments is a reflection of report cards and the family's good name. Keeping a good name as a debtor is very important because it will be useful later in the future. In addition, by prioritizing paying this installment, it means that creditors who have been kind enough to lend money to their families have already appreciated.

Second. After paying debt repayments, the next thing to do is to pay tithes or make religious donations, as one proof of our gratitude to Allah SWT. He is the one who has given the gift of sustenance to all of us so that we can carry out daily economic activities smoothly without deficiencies. So Allah Almighty will increasingly add to the gifts and sustenance that are abundant to us.

Third, what is not less important is to set aside a minimum of $10 \%$ of income for saving/investment. Because, one of the bad habits is to wait for the remaining money at the end of the month, when in reality there is almost always nothing left, that means never being able to save. Fourth. The final step is to spend the remaining salary or income. Good for fulfilling various family routine needs such as shopping for kitchen contents, eating, side dishes, insurance, children's school, recreation, buying clothes and so on.

The general target to be achieved through this activity is to increase the knowledge and ability to manage family management, which usually housewives act as managers. In order to be able to manage family finances in a professional manner, families need to know several key concepts about family financial management. There are two main concepts about family financial management that must be known by the family, namely the Balance Sheet and Profit / Loss and Cash Flow/Cash Flow Management. For more details, see the picture below: 


\section{DIAGRAM CASHFLOW \\ MANAJEMEN KEUANGAN KELUARGA}

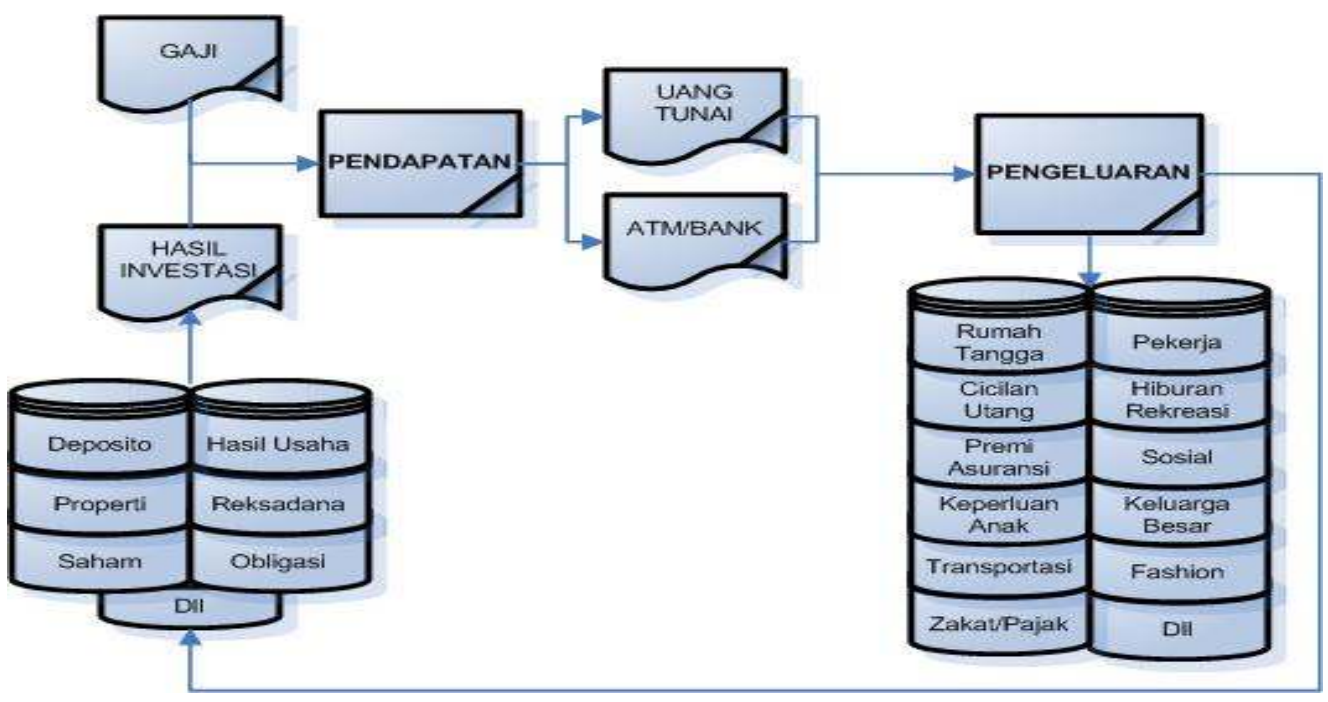

Specifically, the targets to be achieved through the following stages:

Understanding Cashflow. Cashflow or cash flow is the flow of money that starts with we get the money, save it, develop it, and issue it regularly, wisely and discipline. Knowledge of cash flow must be known so that our family's finances will not be chaotic and monitored. There is a pretty interesting phrase "no matter your finances are in a deficit, the important thing is you know where the money is flowing."

Understanding Income. Income is an activity that aims to put money/assets. Usually, income can be obtained from two activities, namely Salary and Investment. Salary is obtained from the status of an employee/employee / professional / consultant. In a family, this salary can be obtained by working husbands and wives. Investment results are obtained from our activities in developing money/assets in various ways. There are several ways to invest, namely Deposits, Property, Shares, Business Results, Mutual Funds, Bonds, and others. All of our income is usually stored in cash or at a bank / ATM.

Understand Expenditures. Expenditure means all activities that result in reduced money. From the diagram, it can be seen that there are many needs for family expenses. So that if it is not regulated properly it will make family finances become chaotic and if it is chronically able to go to the brink of bankruptcy. In general, a family has several expenses such as Household Expenditures, Debt Installments, Insurance Premiums, Domestic Helpers, Children Needs, Transportation, Zakat / Taxes, Entertainment / Recreation, Social Activities, Fashion, and so on.

Understanding Investment. Investment as a source of family income. In fact, if you are diligent in investing, then the results of these investments can actually cover all kinds of our expenses, and can even be far greater than the salary received so far. If the family still relies entirely on the income stream from the salary every month, then it's time to gradually put aside the money so that it can create a new stream of income coming from the investment.

Understanding Notes on Wealth and Profit and Loss Reports. If anyone asks, how much is your net worth at this time? what percentage of your wealth growth compared to last year? What is your income/surplus income this month? What is the percent increase/decrease of your income/surplus income this month compared to the same month in the previous year? Almost many are not ready to give an immediate answer. This is because most of the family does not have a record/report on our family's wealth and profit every period/month. 


\section{METHOD}

The method of implementing this activity refers to family financial management consisting of 4 stages with details of the process stages as follows:

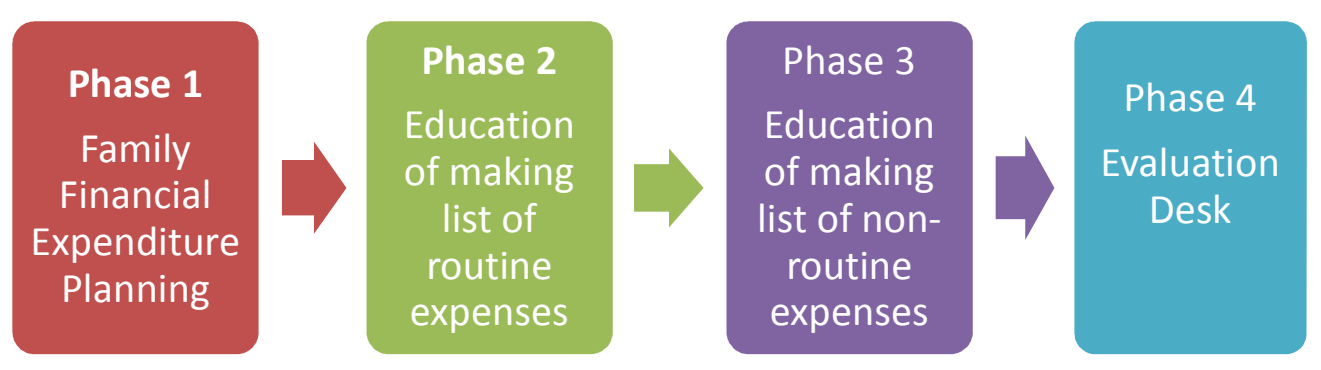

Phase 1: Family Financial Expenditure Planning

The first step that must be done in managing family finances is to record all the income input that the family receives. This is needed so that we can find out how much our family income is per month.

Phase 2: The second step is to make a list of routine expenses that must be spent every month, such as monthly shopping, paying electricity, water, telephone, helpers (if any), children's tuition fees, gas stoves, and others.

Phase 3: The third step is to make a list of non-routine expenses with a priority scale (order of fulfillment). Add up all the expenses in the list, then match the total income we have (reduced by routine needs). If it turns out that the expenditure that we plan exceeds the existing income, then it must be selected again, which expenditure can be delayed.

Phase 4: Evaluation is done to check whether there is an error in the sum of income and expenses, to check the routine needs, to realize which part of the need can be saved/reduced in expenditure, and to notice additional income that may be obtained.

\section{RESULT AND DISCUSSION}

Managing finance is not an easy matter and can be done by everyone. As it is known that human needs are very many, such as eating, drinking, clothing, shelter, education, health, recreation, transportation, etc., while the means of satisfying the needs in the form of money are limited. This is what causes people to say less than more because they don't know how to manage their finances. Through financial management, we will learn how to make decisions based on the priority scale according to the conditions of each family. We can prioritize needs that are very important, important, and less important so that there is hope that there will be money left for future needs by saving. Knowledge and financial management skills are important because every family has different abilities in meeting their needs, both material (physical) and non-material (spiritual) needs. This ability is very dependent on the source of income and the sincerity of the family in achieving it. Through good management, even the limited money can be controlled for its use, so that it will bring prosperity to the family. Likewise, for families who are affluent, financial management is also very important to have, because the desire is unlimited and it is very possible for uncontrolled expenditures to occur.

Based on above description, training was carry out with several activity through field surveys, interviews, and direct practice. Based on the results of interviews with several residents, they urgently need training in family financial management to add knowledge and technical skills to obtain family financial management skills. Related to the identification of the problems that have been submitted, the 
discussion of the expected problems is as providing understanding and knowledge about family financial management to create a prosperous family, as well as providing training and technical skills to the community regarding family financial management, and a simulation of family financial management processes.

Basically, this activity has a good influence to see what has been achieved towards the implementation of financial management that has been prepared as a basis for improving the budget plan for the following month. This activity will also be obtained information about the advantages and disadvantages of our budget plan so that it can be improved or refined for the future

This service activity was held in the framework of the Community Service routine activities as one of the Tri Principles of Higher Education. This activity is carried out well and on time according to what is expected. The number of participants was 30 people.

The training material is distributed to participants regarding theoretical material or practice. Training materials presented in the form of power points and family financial management cases. Training materials are explained interactively in the form of class presentations and discussions. As for the case of family financial management discussed in groups.

From the results of the training evaluation sheet recapitulation, it was found that participants stated that training was very useful to improve understanding regarding the effectiveness of interpersonal communication in family financial management. Factors driving the success of this activity are emerged from a good communication between community service teams, a good cooperation between the community service team and participants, and the enthusiasm of the participants took part in the training until it was finished. Barriers factor comes out from coaching cannot only be done one day because there are quite a lot of participants who have not been skilled in making family financial management, and limited time and funds.

\section{CONCLUSION}

Overall, trainees are dominated by individuals who have a creative spirit. Participants are able to express their ideas and opinions but need time to adjust well in training situations. The thinking patterns of the participants are quite open and flexible.

The class atmosphere is quite lively and 'life'. Creative participants and tend to be brave to express their opinions openly, both in group discussions and individually. The participants stated that the training activities were interesting, many things were 'new' and learned during the activities. Training materials are very useful in 'delivering' participants to better understand family financial management.

This activity can be used as a means of communication, friendship and socialization of Mercu Buana University's Master of Management Postgraduate Program to the community, as well as the realization of the social responsibility of the Institute of Higher Education - Tri Darma Perguruan Tinggi.

The duration of the implementation of training activities can be extended, to two days. Within two days of the implementation of the activities, it is expected that the materials and practices related to family financial management can be delivered more optimally.

\section{REFERENCES}

Gozali A. (2006). Cashflow for Women: Menjadikan Perempuan Sebagai Manajer Keuangan Keluarga Paling Top. Jakarta: Hikmah Populer

Manullang M. (1983). Dasar-dasar Manajemen. Jakarta: Ghalia Indonesia 